\author{
Paweł Nowak \\ Uniwersytet Pedagogiczny im. Komisji Edukacji Narodowej w Krakowie
}

\title{
Rola instytucji państwowych w realizacji polityki konsumenckiej w Polsce
}

DOI: $10.19195 / 1643-0328.21 .10$

Słowa kluczowe: ochrona konsumenta, polityka konsumencka, prawa konsumenta

\section{Wprowadzenie}

Polityka konsumencka znajduje się na obrzeżach polityki publicznej. W Polsce w okresie 1989-1998 była „wtopiona” w politykę gospodarczą, a dopiero później, zwłaszcza od momentu wejścia Polski do Unii Europejskiej w 2004 r., nabrała odrębnego charakteru. Polityka konsumencka, której celem jest ochrona praw konsumentów, realizowana jest poprzez narzędzia pośrednie $\mathrm{w}$ ramach wspierania konkurencji oraz w ramach działań adresowanych bezpośrednio do konsumentów.

Polityka konsumencka jest reakcją państwa na niesprawności rynku powstałe głównie wskutek niepełnej i asymetrycznej informacji na niekorzyść konsumentów. Obecnie znaczenie polityki konsumenckiej rośnie w związku ze wzrostem ryzyka, które spowodowane jest m.in. rosnącą liczbą transakcji zawieranych $\mathrm{z}$ udziałem konsumentów na rynkach zagranicznych.

Celem artykułu jest identyfikacja i ocena roli, jaką odgrywają najważniejsze organy państwowe uczestniczące w realizacji polityki konsumenckiej. Artykuł przedstawia zadania instytucji państwowych chroniących konsumenta oraz zachodzące między nimi relacje w kontekście ostatniej nowelizacji ustawy o ochronie konkurencji i konsumentów. Ocena wprowadzanych zmian dokonywana jest przede wszystkim z punktu widzenia bezpieczeństwa i ochrony interesów ekonomicznych konsumentów. Wnioski określają charakter i kierunek zachodzących zmian prawnych oraz wynikające $\mathrm{z}$ tych zmian konsekwencje dla ochrony konsumentów w Polsce. 


\section{Główne kierunki polityki konsumenckiej}

Współczesna gospodarka to struktura wzajemnie uzupełniających się sektorów prywatnego i publicznego. Tempo rozwoju kraju w wymiarze gospodarczym, społecznym i ekologicznym zależy od właściwego ułożenia relacji pomiędzy tymi sektorami. Sektor prywatny nie mógłby ewoluować bez rozwiniętego sektora publicznego i odwrotnie sektor publiczny jest słaby bez silnego sektora prywatnego. Państwo, reprezentując sektor publiczny, stara się być aktywnym uczestnikiem procesów gospodarczych, nadawać im kierunek i kształtować zgodny z interesem publicznym system bodźców dla uczestników gospodarki.

Polityka konsumencka jest częścią polityki publicznej. Obejmuje świadome działania państwa zmierzające do ukształtowania takich warunków, które umożliwiają jak najlepsze zaspokojenie potrzeb społecznych. Głównym celem polityki konsumenckiej w gospodarce rynkowej jest wzmacnianie konsumenta i ochrona jego interesów w związku z założeniem, że jest on słabszą stroną transakcji ${ }^{1}$.

Polityka konsumencka realizowana jest w następujących obszarach:

- bezpieczeństwa zdrowotnego,

- bezpieczeństwa ekonomicznego i ochrony interesów ekonomicznych konsumentów,

- prawa do reprezentacji,

- efektywnego systemu dochodzenia roszczeń,

- zapewnienia informacji i edukacji.

Dobrobyt społeczeństwa wymaga zapewnienia równowagi sił między przedsiębiorcą a konsumentem. W takich warunkach podział korzyści między stronami transakcji jest bardziej równomierny. Kraje, w których podział dochodu jest bardziej egalitarny, rozwijają się szybciej niż kraje, w których jest on mniej równomierny ${ }^{2}$. Nierównowaga sił jest bezsporna, jeżeli z jednej strony transakcji mamy dużego przedsiębiorcę (korporację), a z drugiej - niewykształconą, starszą osobę jako konsumenta. Takie przypadki dają mocny argument zwolennikom państwowej interwencji.

Jednak w gospodarce, w której działa około 1,8 mln mikroprzedsiębiorców, z zego 1,1 mln nie zatrudnia nikogo, występuje dużo transakcji, w których $\mathrm{z}$ jednej strony mamy samozatrudnionego przedsiębiorcę, a $\mathrm{z}$ drugiej - doskonale wykształconego, świadomego konsumenta ${ }^{3}$. Struktura mikroprzedsiębiorstw według poziomu wykształcenia właściciela wskazuje, że osoby $z$ wykształceniem podstawowym i gimnazjalnym oraz zasadniczym zawodowym stanowią $18 \%$, a $z$ wykształceniem wyższym $-12 \%$ wszystkich samozatrudnionych ${ }^{4}$. Dla osób słabo wykształconych samozatrudnienie jest często jedyną możliwością legalnego zarobkowania. W tej sytuacji przesłanka interwencji odwołująca się do ochrony słabszej strony przestaje być prawdziwa. Słabszą stroną

\footnotetext{
${ }^{1}$ Prawo handlowe dla ekonomistów, red. B. Gnela, Warszawa 2012, s. 163.

2 T. Piketty, Kapitał w XXI wieku, przeł. A. Bilik, Warszawa 2015, s. 721-730.

3 Ministerstwo Gospodarki, Przedsiębiorczość w Polsce, Warszawa 2013, s. 43-44, http://www.me.gov. pl/files/upload/8438/RoP2013_na_str_20130913_w_ost.pdf (dostęp: 10.01.2015).

${ }^{4}$ P. Arak, P. Lewandowski, P. Rakowiecki, Fikcja zatrudnienia w Polsce - propozycje wyjścia z impasu, „IBS Policy Paper” 2014, nr 1, s. 12.
} 
stosunku staje się przedsiębiorca, a działania państwa dodatkowo tę nierównowagę pogłębiają. Dlatego właściwa staje się daleko posunięta ostrożność i profilowanie polityki konsumenckiej - dostosowanej do specyfiki rynków konsumenckich w taki sposób, aby nie hamowała rozwoju.

„Polityka konsumencka na lata 2014-18” jest siódmym programem rządowym, który wskazuje na najistotniejsze kwestie warunkujące skuteczną ochronę interesów i bezpieczeństwa konsumentów w ciągu najbliższych lat ${ }^{5}$. W polityce konsumenckiej w Polsce po 1989 r. można wyróżnić trzy etapy. Pierwszy dotyczy okresu 1989-1998, w którym polityka konsumencka nie była wyodrębniona i stanowiła część polityki gospodarczej, drugi etap przypada na lata 1998-2004, gdy polityka konsumencka tworzyła sprecyzowany obszar działań państwa, i trzeci etap — od 2004 r. — gdy poza tym, że stanowiła politykę szczególną, stała się tożsama z unijnymi programami polityki konsumenckiej ${ }^{6}$. Celem polityki konsumenckiej jest zapewnienie odpowiednich narzędzi prawnych umożliwiających konsumentom skuteczne dochodzenie roszczeń, a także podejmowanie działań informacyjno-edukacyjnych na rzecz eliminowania nielojalnych przedsiębiorców.

Priorytety „Polityki konsumenckiej na lata 2014-2018” można podzielić na ${ }^{7}$ :

— horyzontalne, których celem jest zwiększenie ogólnej ochrony i bezpieczeństwa konsumentów na rynku,

- sektorowe - wyznaczające działania mające zapewnić jak najwyższe standardy przestrzegania praw konsumentów i zwiększania ich świadomości na rynkach, na których występują największe zagrożenia w tym zakresie.

Polityka konsumencka wpisuje się w cele określone w Strategii „Sprawne Państwo 2020" (SSP) ${ }^{8}$. Umiejscowienie zagadnień z zakresu polityki konsumenckiej w strategii poświęconej sprawnemu działaniu państwa jest wyrazem przekonania, że skutki realizacji polityki konsumenckiej nie ograniczają się jedynie do wąsko pojętych stosunków konsumenckich, lecz mają również duży wpływ na skuteczność funkcjonowania struktur państwa oraz na zaufanie obywateli do państwa. Zgodnie z SSP budowa bezpiecznego i prokonsumenckiego rynku to jedno z istotniejszych zadań współczesnego państwa.

Cel ten powinien być realizowany przez wszystkie podmioty, na które został nałożony obowiązek ochrony konsumentów w różnych obszarach rynku. Polityka konsumencka musi stanowić ujednoliconą platformę skupiającą zadania poszczególnych organów publicznych. Ostateczne zbudowanie rynku, na którym konsument będzie równorzędnym uczestnikiem, wymaga skoordynowania działań realizowanych w różnych obszarach rynku, których wspólnym mianownikiem jest ochrona konsumentów.

5 Urząd Ochrony Konkurencji i Konsumentów, „Polityka konsumencka na lata 2014-2018”, Warszawa 2014 r., https://uokik.gov.pl/download.php?plik=14684 (dostęp: 10.11.2015).

6 M. Białczyńska-Biały, Ewolucja polityk konsumenckich w Polsce po 1989 r., Rzeszów 2012, s. 10.

7 „Polityka konsumencka na lata...”

8 Rada Ministrów, Strategia „Sprawne Państwo 2020”, 2013, https://mac.gov.pl/files/wp-content/uploads/2011/12/SSP-20-12-2012.pdf (dostęp: 15.01.2016). 
Cele polityki odzwierciedlają założenia polityki unijnej w zakresie ochrony konsumentów i obejmują m.in. harmonizację prawa ${ }^{9}$. Zasadniczy wpływ na kształt polityki konsumenckiej miało wejście Polski do Unii Europejskiej. We Wspólnocie prawa konsumenta zostały oficjalnie zdefiniowane w Traktacie z Maastricht z 7 lutego 1992 r., który rozszerzył politykę Wspólnoty m.in. o nowy tytuł XI TWE — „Ochronę konsumentów”. Odtąd Wspólnota zobowiązała się do osiągnięcia wysokiego stopnia ochrony konsumentów w zakresie zdrowia i bezpieczeństwa, interesów ekonomicznych oraz udzielania informacji.

Efektywna realizacja polityki konsumenckiej wymaga rzetelnych informacji o zagrożeniach występujących na rynkach oraz o oczekiwaniach nabywców. Instytucje tworzące system ochrony konsumentów powinny dysponować odpowiednimi analizami, które zapewniłyby dostęp do aktualnych informacji o stale zmieniającym się rynku oraz o problemach identyfikowanych przez konsumentów. Wytyczanie celów strategicznych polityki konsumenckiej w oparciu o wiedzę jest jedynym gwarantem, że podejmowane działania będą adekwatne do zmieniających się warunków rynkowych i oczekiwań nabywców.

Uwzględniając wnioski wynikające $\mathrm{z}$ realizacji dotychczasowych sześciu rządowych polityk konsumenckich, można wskazać obszary, w których działania organów wchodzących w skład systemu ochrony konsumentów mogą przyczynić się do dalszego rozwoju przyjaznego konsumentom rynku. Główne kierunki polityki konsumenckiej w świetle „Polityki konsumenckiej na lata 2014-2018” to ${ }^{10}$ :

1. W zakresie priorytetów horyzontalnych:

— zwiększenie skuteczności funkcjonowania systemu ochrony konsumentów,

- rozwój bezpiecznego rynku dla konsumentów,

- wspieranie mechanizmów rozstrzygania sporów oraz prokonsumenckich postaw wśród przedsiębiorców,

— wzmacnianie i rozwój systemu poradnictwa konsumenckiego,

- budowanie świadomości konsumenckiej — polityka informacyjno-edukacyjna,

- rozwój przyjaznego środowiska legislacyjnego w obszarze ochrony konsumentów,

- rozwój współpracy międzynarodowej w zakresie ochrony konsumentów;

2. W zakresie priorytetów sektorowych obejmują zwiększenie bezpieczeństwa ekonomicznego konsumentów na rynku w następujących sektorach:

- usług finansowych,

— usług łączności elektronicznej, usług online oraz usług pocztowych,

- usług przewozów kolejowych,

- wyrobów budowlanych,

- usług turystycznych,

- umów sprzedaży,

— umów sprzedaży towarów i usług zawieranych na odległość lub poza lokalem przedsiębiorcy.

${ }_{9}$ R. Tokarczyk, Problemy harmonizacji polskiej kultury prawnej z kultura prawna Unii Europejskiej, „Studia Europejskie” 2004, nr 3, s. 69.

10 „Polityka konsumencka na lata...” 
Konsekwencją naturalnej dynamiki gospodarki związanej z liberalizacją poszczególnych rynków, rozwojem technologii, a także swobodnym przepływem towarów i usług są nowe zjawiska pojawiające się na rynku, które w bezpośredni sposób wpływają na interesy konsumentów. Celem Rządu RP jest zatem zapewnienie konsumentom poczucia bezpieczeństwa przy zawieraniu umów sprzedaży towarów oraz świadczenia usług. Dotyczy to w równym stopniu transakcji realizowanych w sposób tradycyjny, jak również umów zawieranych na odległość lub poza lokalem przedsiębiorcy, niezależnie od rodzaju towaru, kanału dystrybucji oraz kraju pochodzenia.

\section{Instytucje realizujące politykę konsumencką}

Doświadczenia zebrane w trakcie realizacji poprzednich polityk konsumenckich wskazują na wiele instytucji wchodzących w skład systemu ochrony konsumentów przy niedostatecznym poziomie identyfikacji przez konsumentów kompetencji poszczególnych organów ${ }^{11}$. Jednocześnie analiza dotychczasowych działań organów państwowych zajmujących się ochroną interesów konsumentów wskazuje na potrzebę ścisłej koordynacji podejmowanych przez nie działań, co jest zgodne z przewidzianym w SSP postulatem zwiększenia koordynacji i współpracy przy realizacji zadań publicznych.

W polityce konsumenckiej główny ciężar jej realizacji spoczywa na Prezesie Urzędu Ochrony Konkurencji i Konsumentów (UOKiK). Uwzględniając podejście instytucjonalne do rządowej polityki konsumenckiej, należałoby ją postrzegać bardziej w kontekście działań w ramach wielopłaszczyznowego systemu niż pojedynczych organów lub instytucji realizujących zadania związane z ochroną konsumentów. Instytucje realizujące politykę konsumencką i zadania związane z ochroną konsumentów stanowią system ochrony nabywców. Do podmiotów realizujących tę politykę należą ${ }^{12}$ :

- organy państwowe, w których skład wchodzą organy administracji rządowej oraz organy kontroli państwowej,

— inne podmioty działające w sferze administracji państwowej,

— organy administracji samorządowej,

- organizacje pozarządowe, których zadaniem jest ochrona praw konsumentów.

Efektywna realizacja założeń polityki konsumenckiej jest w dużym stopniu uzależniona od ścisłej współpracy z organizacjami konsumenckimi, na których spoczywa część zadań związanych z ochroną konsumentów.

11 A. Dąbrowska, Ochrona i edukacja konsumentów na wybranych rynkach usług, Warszawa 2013, s. 146-155; G. Rokicka, Pozycja konsumentów na polskim rynku artykułów gospodarstwa domowego. Wyniki konsumenckiego badania ankietowego, Warszawa 2004, s. 12-16.

12 A. Dąbrowska, M. Janoś-Kresło, I. Ozimek, Ochrona i edukacja konsumentów we wspótczesnej gospodarce rynkowej, Warszawa 2005, s. 54-90. 


\begin{tabular}{|c|c|c|}
\hline \multirow{20}{*}{ 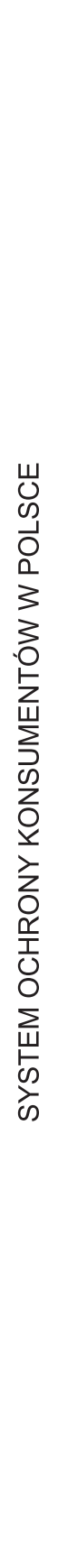 } & \multicolumn{2}{|c|}{$\begin{array}{l}\text { Prezes UOKiK podejmuje działania horyzontalne przez monitorowanie, } \\
\text { analizowanie i sprawowanie kontroli nad rynkiem konsumenckim, } \\
\text { podnoszenie świadomości uczestników obrotu odnośnie do przysługujących } \\
\text { konsumentom praw, wspieranie rozwoju dialogu konsumenckiego } \\
\text { oraz efektywnego poradnictwa }\end{array}$} \\
\hline & \multirow{6}{*}{$\begin{array}{l}\text { Organy administracji rządowej, działające } \\
\text { na określonych obszarach rynku i pełniące } \\
\text { funkcję regulatorów. Mają kompetencje } \\
\text { wynikające z ustaw szczególnych, } \\
\text { do podejmowania działań w określonych } \\
\text { obszarach rynku, w tym zakresie podejmują } \\
\text { również działania związane } \\
\text { z ochroną konsumentów }\end{array}$} & UKE \\
\hline & & URE \\
\hline & & UTK \\
\hline & & KNF \\
\hline & & ULC \\
\hline & & GIODO \\
\hline & \multirow{5}{*}{$\begin{array}{l}\text { Organy kontroli państwowej, działające } \\
\text { na określonych obszarach rynku i pełniące } \\
\text { funkcję kontrolno-inspekcyjną. Prowadzą } \\
\text { działania w obszarze wyznaczonego rynku, } \\
\text { w zakresie swojej właściwości podejmują się } \\
\text { również zadań związanych z ochroną konsumenta }\end{array}$} & PIS \\
\hline & & GIF \\
\hline & & $\rightarrow$ IJHARS \\
\hline & & $\mathrm{IH}$ \\
\hline & & URPL \\
\hline & \multirow{3}{*}{$\begin{array}{l}\text { Podmioty działające w strukturze administracji } \\
\text { publicznej, niebędące organami administracji, } \\
\text { do których zadań należy m.in. pomoc } \\
\text { konsumentom w rozstrzyganiu sporów } \\
\text { krajowych i transgranicznych }\end{array}$} & RZU \\
\hline & & ECK \\
\hline & & $\begin{array}{l}\text { ADR-y - tworzone } \\
\text { przez podmioty } \\
\text { publiczne }\end{array}$ \\
\hline & \multirow{3}{*}{$\begin{array}{l}\text { Organy samorządowe zajmujące się pomocą } \\
\text { konsumentom w indywidualnych sprawach }\end{array}$} & \multirow{2}{*}{$\begin{array}{l}\text { Powiatowy Rzecznik } \\
\text { Konsumentów }\end{array}$} \\
\hline & & \\
\hline & & $\begin{array}{l}\text { Miejski Rzecznik } \\
\text { Konsumentów }\end{array}$ \\
\hline & \multirow{2}{*}{$\begin{array}{l}\text { Organizacje (podmioty) pozarządowe } \\
\text { zajmujące się ochroną praw konsumenckich }\end{array}$} & \begin{tabular}{|l|} 
Organizacje \\
konsumenckie
\end{tabular} \\
\hline & & $\begin{array}{l}\text { ADR-y - tworzone przez } \\
\text { organizacje pozarządowe }\end{array}$ \\
\hline
\end{tabular}

Rycina 1. System ochrony konsumentów w Polsce

Źródło: „Polityka konsumencka na lata 2014-2018”. 
Instytucjonalną ochronę konsumenta w Polsce tworzą przede wszystkim następujące organy:

- Prezes UOKiK oraz Urząd Ochrony Konkurencji i Konsumentów (UOKiK),

- Inspekcja Handlowa,

- Powiatowy (Miejski) Rzecznik Konsumentów.

Prezes UOKiK to rządowy organ koordynujący i monitorujący całokształt działań z zakresu ochrony konsumentów, podległy Prezesowi Rady Ministrów. Urząd Ochrony Konkurencji i Konsumentów jest aparatem wykonawczym dla Prezesa UOKiK, który odgrywa wiodącą rolę w kwestii ochrony konkurencji, a od 1996 roku odpowiedzialny jest również za ochronę interesów konsumentów. Dzięki nadzorowi Prezesa UOKiK nad działaniami w ramach polityki konsumenckiej są one skoncentrowane i bardziej skutecz$\mathrm{ne}^{13}$. Jednym $\mathrm{z}$ ustawowych uprawnień Prezesa UOKiK jest kompetencja do prowadzenia postępowań w sprawach praktyk naruszających zbiorowe interesy konsumentów. Ich efektem jest m.in. przyczynianie się do zwiększenia przejrzystości wzorców umownych i eliminowania $\mathrm{z}$ rynku tych wzorców, które nie spełniają wymogu transparentności, tj. zrozumiałości tekstu oraz czytelnego sposobu przedstawienia postanowień umownych.

Dotychczasowe działania Prezesa UOKiK w zakresie sektorowych kontroli wzorców umownych stosowanych $\mathrm{w}$ obrocie $\mathrm{z}$ konsumentami doprowadziły do eliminacji wielu nieprawidłowości na rynku. Istotna część najczęściej stosowanych postanowień, które spełniają ustawowe przesłanki uznania ich za niedozwolone, znajduje swój odpowiednik w prowadzonym przez Prezesa UOKiK rejestrze niedozwolonych postanowień umownych. Wydano 1165 decyzji stwierdzających naruszenie zbiorowych interesów konsumentów w czasie obowiązywania poprzedniej „Polityki konsumenckiej”.

Do kompetencji Prezesa UOKiK należy realizowanie rządowej polityki ochrony konsumentów. Jego uprawnienia w zakresie ochrony konsumentów obejmują:

- występowanie w interesie publicznym - to znaczy wszczynanie postępowań administracyjnych o naruszenie zbiorowych interesów konsumentów. Prezes Urzędu może wydać decyzję, która będzie zakazywała stosowania praktyk naruszających prawa konsumentów oraz może nałożyć karę pieniężną na przedsiębiorców,

- prawo kontroli wzorców stosowanych w umowach z udziałem konsumentów. W jego następstwie do Sądu Ochrony Konkurencji i Konsumentów kierowane są pozwy o uznanie klauzul za niedozwolone,

— opiniowanie ustaw i innych aktów prawnych — dbanie o to, by w należytym stopniu uwzględniały one interesy konsumentów,

- inicjowanie zmian legislacyjnych zmierzających do zapewnienia konsumentom pełniejszej ochrony,

- wszczynanie postępowań administracyjnych po otrzymaniu informacji o zagrożeniach. W ich wyniku Prezes UOKiK może wydać decyzję i zakazać wprowadzania produktu na rynek, nakazać odpowiednio oznakować dany produkt lub wycofać go z rynku.

${ }^{13}$ M. Niepokulczycka, Polityka konsumencka i ochrona interesów konsumentów. Materiały dla pracowników i działaczy samorządu terytorialnego, Warszawa 1999, s. 31. 
Działania Prezesa UOKiK w ramach interesu publicznego nie są realizowane jedynie przez środki o charakterze władczym. Obejmują one także aktywność edukacyjną i informacyjną - w szczególności w zakresie, w jakim zaobserwowano u konsumentów mniejszy poziom świadomości co do przysługujących im uprawnień, a także monitoring rynku - zwłaszcza tych jego obszarów, w których dostrzeżono nieprawidłowości o szczególnie dotkliwych dla konsumentów skutkach.

Inspekcja Handlowa $(\mathrm{IH})$ jest wyspecjalizowanym organem kontroli powołanym do ochrony interesów i praw konsumentów oraz interesów gospodarczych państwa. Jest organem administracji publicznej podległym Prezesowi UOKiK. Z dniem 31 grudnia 2008 r. zlikwidowany został Główny Inspektorat Inspekcji Handlowej oraz Główny Inspektor Inspekcji Handlowej będący jej organem. Jednocześnie na mocy zarządzenia Prezesa Rady Ministrów z dniem 23 grudnia 2008 r. Inspekcja Handlowa stała się jedną z jednostek organizacyjnych UOKiK podległych Prezesowi UOKiK. Dzięki tym zmianom nastąpiła likwidacja zbędnego ogniwa, uproszczenie struktur administracyjnych i usprawnienie działania tego urzędu. Obecnie Prezes UOKiK określa kierunki działań IH i zleca bezpośrednio wojewódzkim inspektoratom IH przeprowadzanie kontroli.

Podstawowym zadaniem realizowanym przez organy IH jest kontrola legalności i rzetelności działania przedsiębiorców oraz kontrola produktów i usług wprowadzonych do obrotu. Do zadań IH należy także prowadzenie Stałych Polubownych Sądów Konsumenckich. W grudniu 1991 r. zostały powołane przez Krajową Radę Federacji Konsumentów oraz Główny Inspektorat Państwowej Inspekcji Handlowej polubowne sądy konsumenckie jako instytucja rozstrzygania sporów z zakresu umów sprzedaży. Obecnie sądy polubowne prowadzą wojewódzkie inspektoraty IH na mocy ustawy z 24 lipca 1996 r. o zmianie niektórych ustaw określających kompetencje organów administracji publicznej w związku z reformą ustrojową państwa.

Działania IH odnoszą się do ochrony przed towarami zagrażającymi życiu lub zdrowiu konsumentów oraz ochrony ich ekonomicznych interesów. W praktyce oznacza to przede wszystkim koncentrowanie się na:

- badaniu jakości towarów i usług,

- monitorowaniu oszustw i innych nieprawidłowości występujących przy sprzedaży produktów żywnościowych, przemysłowych i usług,

— poradnictwie konsumenckim i szeroko rozumianej edukacji konsumenckiej,

- podejmowaniu mediacji w celu ochrony interesów i praw konsumentów.

Zgodnie $\mathrm{z}$ obowiązującym prawem $\mathrm{w}$ sprawach indywidualnych bezpłatną pomoc prawną konsumenci mogą uzyskać od powiatowych (miejskich) rzeczników konsumentów. Od 1 stycznia 1999 r. w związku z reformą administracyjną powstał nowy podmiot - powiatowy (miejski) rzecznik konsumentów. W ten sposób ochrona praw konsumentów znalazła się wśród zadań samorządu powiatowego. Obecnie w Polsce działa 369 rzeczników konsumentów. Ich aktywność przejawia się w dwóch zasadniczych formach: pozaprocesowej i procesowej ${ }^{14}$.

${ }^{14}$ M. Białczyńska-Biały, op. cit., s. 110. 
Do kompetencji rzeczników w szczególności należą:

- zapewnienie bezpłatnego poradnictwa konsumenckiego i informacji prawnej w zakresie ochrony interesów konsumentów,

- składanie wniosków w sprawie stanowienia lub zmiany przepisów prawa miejscowego w zakresie ochrony interesów konsumentów,

- występowanie do przedsiębiorców w sprawach ochrony praw i interesów konsumentów,

- wytaczanie powództw na rzecz konsumentów i wstępowanie za ich zgodą do toczącego się postępowania.

Rzecznicy są zobowiązani do współpracy z IH w zakresie wymiany informacji o praktykach naruszających prawa konsumentów i wynikach kontroli. Współdziałanie dotyczy również udziału w kontrolach i mediacjach prowadzonych przez IH. Rzecznicy zobowiązani są także do współdziałania z organami pozarządowymi oraz delegaturami UOKiK. 30 marca 2001 r. została powołana Krajowa Rada Rzeczników Konsumentów jako organ działający przy Prezesie UOKiK. Pełni ona funkcję opiniodawczo-doradczą.

\section{Zmiany w systemie ochrony konsumentów}

System ochrony konsumentów uległ istotnej zmianie w wyniku nowelizacji ustawy o ochronie konkurencji i konsumentów z dnia 16 lutego 2007 r. przez uchwalenie ustawy z dnia 5 sierpnia 2015 r. o zmianie ustawy o ochronie konkurencji i konsumentów oraz niektórych innych ustaw (Dz.U. z 2015 r. poz. 1634), która wchodzi w życie 17 kwietnia 2016 r. owe przepisy przewidują istotne wzmocnienie uprawnień Prezesa UOKiK w zakresie ochrony zbiorowych interesów konsumentów. Zmiany mają znaczący wpływ zarówno na działalność przedsiębiorców, jak i sposób egzekucji prawa przez Prezesa UOKiK.

Główne cele nowelizacji to:

— szybsze eliminowanie niekorzystnych dla konsumentów praktyk rynkowych,

- usprawnienie kontroli klauzul niedozwolonych.

Najważniejsze zmiany wprowadzone przez nowelizację ustawy o ochronie konkurencji i konsumentów obejmują ${ }^{15}$ :

- zakaz proponowania konsumentom nabycia usług finansowych, które nie odpowiadają ich potrzebom oraz proponowanie nabycia tych usług w sposób nieadekwatny do ich charakteru,

- wprowadzenie decyzji tymczasowych,

- wprowadzenie instytucji „tajemniczego klienta”, która pozwoli na uzyskanie dowodów w postępowaniu w sprawie praktyk naruszających zbiorowe interesy konsumentów,

- nowy model kontroli postanowień wzorców umów,

- publikowanie bezpłatnych komunikatów i ostrzeżeń w publicznym radiu i telewizji,

- możliwość wyrażenia poglądu w sprawie.

15 Ustawa z dnia 5 sierpnia 2015 r. o zmianie ustawy o ochronie konkurencji i konsumentów oraz niektórych ustaw, Dz.U. z 2015 r. poz. 1634. 
Nowelizacja stara się ograniczyć problem tzw. missellingu, czyli sprzedaży produktów niedopasowanych do potrzeb konsumentów. Dotyczy on w szczególności niektórych produktów finansowych, których stopień skomplikowania wyklucza możliwość oceny ich przydatności przez przeciętnego konsumenta. Przykładem takich produktów są przede wszystkim ubezpieczenia na życie i tzw. polisolokaty. Nowelizacja wprowadza zakaz proponowania konsumentom nabycia usług finansowych nieodpowiadających ich potrzebom. Celem jest wymuszenie na przedsiębiorcach etycznego postępowania w zakresie proponowania konsumentom produktów finansowych, zakaz proponowania konsumentom nabycia usług finansowych, które nie odpowiadają ich potrzebom ustalonym z uwzględnieniem dostępnych przedsiębiorcy informacji w zakresie cech konsumentów oraz zakaz proponowania nabycia takich usług w sposób nieadekwatny do ich charakteru.

Prezes UOKiK zyskał uprawnienie do wydawania decyzji tymczasowych $w$ sprawie praktyk zagrażających zbiorowym interesom konsumentów, podobnie jak w sprawie praktyk naruszających konkurencję. Takie decyzje będą miały rygor natychmiastowej wykonalności - strona będzie mogła decyzję skarżyć, lecz wniesienie odwołania nie wstrzyma jej wykonania. Decyzja tymczasowa będzie wydawana na czas nie dłuższy niż do wydania decyzji kończącej postępowanie w sprawie. Przedsiębiorca będzie miał możliwość złożenia odwołania od decyzji tymczasowej. W takiej sytuacji UOKiK przekaże akta sprawy do Sądu Ochrony Konkurencji i Konsumentów (SOKiK) nie później niż w ciągu 10 dni od dnia otrzymania odwołania, a ten będzie miał na rozpatrzenie odwołania 2 miesiące od dnia jego przekazania przez Prezesa UOKiK.

Nowelizacja ustawy wprowadza instytucję tzw. tajemniczego klienta, która ma umożliwić zakup towaru w celu zdobycia dowodu. Ułatwi to Prezesowi UOKiK wywiązanie się z ciążącego na nim obowiązku udowodnienia przedsiębiorcy naruszenia przepisów ustawy o ochronie konkurencji i konsumentów. Prezes UOKiK będzie mógł, za zgodą sądu, sprawdzić w praktyce sposób oferowania każdego produktu lub usługi oraz procedurę zawierania umowy z konsumentem. Należy jednak zaznaczyć, iż czynności podejmowane przez „tajemniczego klienta” w stosunku do przedsiębiorców będą wymagały uzyskania przez UOKiK zgody sądu, który wydaje odpowiednie postanowienie w ciągu 48 godzin od złożenia wniosku przez Prezesa UOKiK.

Ustawa ma również za zadanie usprawnienie systemu eliminowania $\mathrm{z}$ obrotu niedozwolonych postanowień wzorców umów zawieranych z konsumentami. Zgodnie $\mathrm{z}$ art. $385^{1}$ Kodeksu cywilnego są to takie postanowienia, które kształtują prawa i obowiązki konsumenta w sposób sprzeczny z dobrymi obyczajami, rażąco naruszając jego interesy, z wyjątkiem postanowień określających główne świadczenia stron, sformułowanych w sposób jednoznaczny. Ustawa wprowadza zmianę modelu kontroli postanowień wzorców umów - odejście od modelu sądowego orzekania o klauzulach niedozwolonych na rzecz postępowania administracyjnego prowadzonego przez Prezesa UOKiK. Od rozstrzygnięcia będzie przysługiwało odwołanie do SOKiK, który zbada sprawę jako sąd I instancji, gdzie Prezes UOKiK będzie pozwanym, a przedsię- 
biorca powodem. Do sądu nie trafiają sprawy błahe, w których nie ma sporu. Zmiana ta powinna $\mathrm{w}$ praktyce przyspieszyć proces kontroli wzorców umów, co stanowi dla przedsiębiorców wyraźny sygnał, aby przykładali większą wagę do formułowania treści umów zawieranych $\mathrm{z}$ konsumentami. UOKiK będzie mógł nakazać w ramach usunięcia skutków praktyki wysłanie do konsumentów propozycji aneksowania umów przez usunięcie spornych postanowień.

Postępowanie w sprawie o uznanie postanowień wzorca umowy za niedozwolone powinno zostać zakończone $\mathrm{w}$ terminie 4 miesięcy, a w sprawie szczególnie skomplikowanej -5 miesięcy. Przy czym nie wszczyna się postępowania w sprawie o uznanie postanowień wzorca umowy za niedozwolone, jeżeli od końca roku, w którym zaprzestano ich stosowania, upłynęły 3 lata. Prezes UOKiK może wydać decyzję o nałożeniu na przedsiębiorcę kary pieniężnej w wysokości do 10000 euro za każdy dzień opóźnienia w wykonaniu decyzji lub wyroków sądowych, m.in. w sprawach o stosowanie niedozwolonych postanowień wzorców umów.

Prezes UOKiK uzyskał możliwość publikowania bezpłatnych komunikatów i ostrzeżeń o zachowaniach przedsiębiorców lub zjawiskach zagrażających interesom konsumentów w publicznym radiu i telewizji. Działanie to będzie miało charakter niewątpliwie zniechęcający do zakupu usług lub produktów będących przedmiotem komunikatu.

Prezes UOKiK będzie mógł również wyrazić swój pogląd w indywidualnej sprawie przed sądem powszechnym, jeżeli przemawia za tym interes publiczny. Pozwoli to dzielić się z sądami wiedzą i dorobkiem orzeczniczym z zakresu prawa ochrony konkurencji i konsumentów, co umożliwi sądowi powszechnemu lepsze rozpoznanie sprawy.

Polityka konsumencka nie jest oczywistym elementem polityki gospodarczej we współczesnych krajach o gospodarce rynkowej, ponieważ bywa „wtopiona” w politykę ochrony konkurencji. Jest odpowiedzią na niedoskonałości rynku powstałe w wyniku niedoskonałej i asymetrycznej informacji ${ }^{16}$. Jej uzasadnienie wynika również z ograniczeń behawioralnych, jakie widać w decyzjach konsumenckich.

Analiza wprowadzonych zmian w systemie ochrony konsumenta wskazuje, że rozwijany jest model oparty na rosnących uprawnieniach kontrolnych organów władzy państwowej. Model ten cechuje rosnąca koncentracja władzy w rękach Prezesa UOKiK. Sądzę, że nie ma podstaw, aby ten kierunek zmian wpłynął istotnie na poprawę bezpieczeństwa konsumentów, zwłaszcza w wymiarze ekonomicznym. Wydaje się, że za dużo od państwa oczekujemy i mu powierzamy ${ }^{17}$. Takie podejście tworzy pozory bezpieczeństwa.

Prowadzona polityka konsumencka nie spełnia zaleceń zawartych w OECD Consumer Policy Toolkit $^{18}$. Brakuje w niej wyraźnie ewaluacji skutków i powiązania wyników

16 P. Nowak, Ochrona konsumenta w warunkach asymetrii informacji. „Zeszyty Naukowe AE” 2003, nr 594, s. 91-100.

17 T. Geodecki et al., Konkurencyjna Polska. Jak awansować w światowej lidze gospodarczej?, Kraków 2013, s. 129.

18 OECD Consumer Policy Toolkit, http://docplayer.pl/11963541-Consumer-policy-toolkit-summaryin-polish-zestaw-narzedzi-polityki-ochrony-konsumentow-streszczenie-w-jezyku-polskim.html (dostęp: 6.01.2016). 
oceny z procesami decyzyjnymi. Inercja polityki jest bardzo duża. Wzrost liczby danych nie przekłada się na stopień ich wykorzystania w polityce konsumenckiej. Brak refleksyjności i zdolności do uczenia się struktur administracyjnych jest wyraźnie widoczny ${ }^{19}$. Skuteczność polityki konsumenckiej bada się tylko w niektórych krajach, np. w Austrii i Wielkiej Brytanii ${ }^{20}$. Brytyjski Office of Fair Trading zaleca testowanie rozwiązań w ramach eksperymentów laboratoryjnych, zanim zostaną one wprowadzone w życie. $\mathrm{W}$ procesie legislacyjnym powinny być przedstawione wyliczenia dotyczące konsekwencji społecznych i ekonomicznych wprowadzanych zmian.

\section{Podsumowanie}

We współczesnej gospodarce konsumenci działają często na rynkach o niskim stopniu konkurencji, które charakteryzuje m.in. niedoskonała informacja uczestników, wysokie koszty transakcyjne i duża dysproporcja siły rynkowej. Do tego dochodzą ograniczenia behawioralne konsumentów polegające na braku zdolności do właściwej oceny sytuacji i podjęcia racjonalnej decyzji. Cechy te ujawniają się ze szczególną siłą w dobie globalizacji, która powoduje przeciążenie informacyjne i rosnące zagubienie konsumentów.

Poziom bezpieczeństwa konsumentów obniża się w wyniku zmian cywilizacyjnych. Szum informacyjny oraz pośpiech powodują, że konsumentom jest coraz trudniej podejmować decyzje. Nie wydaje się, aby państwo było w stanie tę tendencję zatrzymać lub odwrócić. Pojawia się więc pytanie: „co może zrobićc?”.

Najbardziej sensowne, oczywiście tam, gdzie to wystarczy, wydaje się rozwijanie prewencji i kładzenie nacisku na zapobieganie podejmowaniu złych decyzji. Negatywnych zmian cywilizacyjnych nie da się zatrzymać, można jedynie ograniczyć ich negatywne skutki. Edukacja konsumencka w szkołach jest bardzo potrzebna. Kształcenie m.in. na temat odbioru reklam, czytania opakowań, podpisywania umów kredytowych, zakupu mieszkania, oceny taryf ma duże znaczenie w podejmowaniu powszechnych decyzji. Dlatego też większą rolę w polityce konsumenckiej powinny odgrywać kampanie informacyjno-edukacyjne finansowane ze środków publicznych.

Sądzę, że zmiana podejścia w kierunku samoograniczenia, umiaru, świadomej rezygnacji z tego, co zbędne, będzie konieczna, aby utrzymać poziom dobrostanu przy malejącym dobrobycie materialnym ${ }^{21}$. Polityka konsumencka powinna wychodzić naprzeciw zachodzącym zmianom, oraz uruchamiać istniejące rezerwy, które występują w obszarze stosunków międzyludzkich i samoorganizacji rynków.

19 T. Geodecki et al., Kurs na innowacje. Jak wyprowadzić Polskę z rozwojowego dryfu?, Kraków 2012, s. $39-50$.

20 M. Lissowska, Polityka konsumencka - źródła pojęcia, narzędzia, s. 22, http://kolegia.sgh.waw.pl/pl/ KAE/struktura/IRG/publikacje/Documents/pim85_2.pdf (dostęp: 12.02.2016).

21 G.W. Kołodko, Dokąd zmierza świat. Ekonomia polityczna przyszłości, Warszawa 2013, s. 300. 


\section{Bibliografia}

Arak P., Lewandowski P., Rakowiecki P., Fikcja zatrudnienia w Polsce - propozycje wyjścia z impasu, „IBS Policy Paper" 2014, nr 1.

Białczyńska-Biały M., Ewolucja polityk konsumenckich w Polsce po 1989 r., Wydawnictwo Uniwersytetu Rzeszowskiego, Rzeszów 2012.

Dąbrowska A., Ochrona i edukacja konsumentów na wybranych rynkach usług, PWE, Warszawa 2013.

Dąbrowska A., Janoś-Kresło M., Ozimek I., Ochrona i edukacja konsumentów we współczesnej gospodarce rynkowej, PWE, Warszawa 2005.

Geodecki T. et al., Konkurencyjna Polska. Jak awansować w światowej lidze gospodarczej?, Fundacja Gospodarki i Administracji Publicznej, Kraków 2013.

Geodecki T. et al., Kurs na innowacje. Jak wyprowadzić Polskę z rozwojowego dryfu?, Fundacja Gospodarki i Administracji Publicznej, Kraków 2012.

Kołodko G.W., Dokąd zmierza świat. Ekonomia polityczna przyszłości, Pruszyński i S-ka, Warszawa 2013.

Lissowska M., Polityka konsumencka - podstawy teoretyczne, cele i narzędzia, „Gospodarka Narodowa” 2010, nr 10.

Niepokulczycka M., Polityka konsumencka i ochrona interesów konsumentów. Materiały dla pracowników i działaczy samorzadu terytorialnego, SKP, Warszawa 1999.

Nowak P., Ochrona konsumenta w warunkach asymetrii informacji, „Zeszyty Naukowe AE” 2003, nr 594.

Piketty T., Kapitat w XXI wieku, przeł. A. Bilik, Wydawnictwo Krytyki Politycznej, Warszawa 2015.

Prawo handlowe dla ekonomistów, red. B. Gnela, Wolters Kluwer Polska, Warszawa 2012.

Rokicka G., Pozycja konsumentów na polskim rynku artykułów gospodarstwa domowego. Wyniki konsumenckiego badania ankietowego, Stowarzyszenie Konsumentów Polskich, Warszawa 2004.

Tokarczyk R., Problemy harmonizacji polskiej kultury prawnej z kultura prawnq Unii Europejskiej, „Studia Europejskie" 2004, nr 3.

Ustawa z dnia 5 sierpnia 2015 r. o zmianie ustawy o ochronie konkurencji i konsumentów oraz niektórych ustaw, Dz.U. z 2015 r. poz. 1634.

\section{Źródła internetowe}

Consumer Policy Toolkit, http://docplayer.pl/11963541-Consumer-policy-toolkit-summary-in-polish-zestawnarzedzi-polityki-ochrony-konsumentow-streszczenie-w-jezyku-polskim.html.

Lissowska M., Polityka konsumencka - źródła, pojęcia, narzędzia, s. 22, http://kolegia.sgh.waw.pl/pl/KAE/ struktura/IRG/publikacje/Documents/pim85_2.pdf.

Ministerstwo Gospodarki, Przedsiębiorczość w Polsce, Warszawa 2013, http://www.me.gov.pl/files/upload/8438/RoP2013_na_str_20130913_w_ost.pdf.

Rada Ministrów, Strategia „Sprawne Państwo 2020”, 2013, https://mac.gov.pl/files/wp-content/uploads/2011 /12/SSP-20-12-2012.pdf.

Urząd Ochrony Konkurencji i Konsumentów, „Polityka konsumencka na lata 2014-2018”, Warszawa 2014, https://uokik.gov.pl/download.php?plik=14684. 


\section{The role of governmental institutions in the implementation of consumer policy in Poland}

Keywords: consumer protection, consumer policy, consumer rights

Summary

The paper is concerned with the law and governmental protection of the position of a consumer in Poland. The main purpose is the identification and evaluation of activities undertaken by governmental institutions engaged in consumer policy. The paper defines the set of tasks of governmental institutions and the main relations between them is the aspect of antimonopoly law. First of all the focus is put on the issue of protection of economic consumer rights. The results show that the model of consumer protection is overdeveloped when it comes to law and administrative changes and underdeveloped in the consumer education aspect. 